\title{
Genetic Diversity of Salt Tolerance in Miscanthus
}

\author{
Chang-Lin Chen ${ }^{1,2}$, Hanneke van der Schoot ${ }^{1}$, Shiva Dehghan ${ }^{1}$, Claire L. Alvim Kamei ${ }^{1,3}$, \\ Kai-Uwe Schwarz ${ }^{4}$, Heike Meyer ${ }^{4}$, Richard G. F. Visser ${ }^{1}$ and C. Gerard van der Linden ${ }^{1 *}$ \\ ${ }^{1}$ Plant Breeding, Wageningen University and Research, Wageningen, Netherlands, ${ }^{2}$ Graduate School Experimental Plant \\ Science, Wageningen University and Research, Wageningen, Netherlands, ${ }^{3}$ Department of Comparative Development and \\ Genetics, Max Planck Institute for Plant Breeding Research, Cologne, Germany, ${ }^{4}$ Julius Kühn-Institute, Institute for Crop and \\ Soil Science, Braunschweig, Germany
}

Miscanthus is a woody rhizomatous $\mathrm{C} 4$ grass that can be used as a $\mathrm{CO}_{2}$ neutral biofuel resource. It has potential to grow in marginal areas such as saline soils, avoiding competition for arable lands with food crops. This study explored genetic diversity for salt tolerance in Miscanthus and discovered mechanisms and traits that can be used to improve the yield under salt stress. Seventy genotypes of Miscanthus (including $57 \mathrm{M}$. sinensis, $5 \mathrm{M}$. sacchariflorus, and 8 hybrids) were evaluated for salt tolerance under saline (150 $\mathrm{mM} \mathrm{NaCl})$ and normal growing conditions using a hydroponic system. Analyses of shoot growth traits and ion concentrations revealed the existence of large variation for salt tolerance in the genotypes. We identified genotypes with potential for high biomass production both under control and saline conditions that may be utilized for growth under marginal, saline conditions. Several relatively salt tolerant genotypes had clearly lower $\mathrm{Na}^{+}$concentrations and showed relatively high $\mathrm{K}^{+} / \mathrm{Na}^{+}$ratios in the shoots under salt stress, indicating that a $\mathrm{Na}^{+}$exclusion mechanism was utilized to prevent $\mathrm{Na}^{+}$ accumulation in the leaves. Other genotypes showed limited reduction in leaf expansion and growth rate under saline conditions, which may be indicative of osmotic stress tolerance. The genotypes demonstrating potentially different salt tolerance mechanisms can serve as starting material for breeding programs aimed at improving salinity tolerance of Miscanthus.

Keywords: Miscanthus, salt tolerance, osmotic stress, ionic stress, ion homeostasis

\section{INTRODUCTION}

Miscanthus is a C4 perennial grass originating from Southeast Asia, the Pacific islands, and tropical Africa. The genus Miscanthus has a basic chromosome number of 19, and includes the nominally diploid species Miscanthus sinensis $(2 \mathrm{~N}=2 \mathrm{x}=38)$ and tetraploid species Miscanthus sacchariflorus $(2 \mathrm{~N}=4 \mathrm{x}=76)$ plus a triploid interspecific hybrid, Miscanthus $\times$ giganteus $(3 \mathrm{n}=3 \mathrm{x}=57)$. This hybrid was identified as a good candidate for energy production by direct combustion (Zub and Brancourt-Hulmel, 2010). However, Miscanthus $\times$ giganteus has several disadvantages. Since Miscanthus $\times$ giganteus is a sterile triploid, it is difficult to improve its genetics by crossing. In addition, its sterility requires propagation from rhizomes or tissue culture, which is relatively more expensive than from seeds (Greef and Deuter, 1993). To screen and explore natural genetic diversity from other sources is therefore important for genetic improvement of the crop. A good alternative for breeding purposes is the diploid species M. sinensis. An important breeding goal for 
any bioenergy crop and also Miscanthus is to achieve economically viable yields in marginal lands, thus avoiding competition with food crops and interfering with food security (Somerville et al., 2010).

High soil salinity is one of the major constraints of crop growth because it decreases crop yield and quality. Almost $20 \%$ of the world's irrigated land is adversely influenced by salinity (Flowers and Yeo, 1995; Munns and Tester, 2008; Rengasamy, 2010b; Qadir et al., 2014), and the problem of soil salinity is further increasing because of poor drainage and climatic change (Bennett and Khush, 2003). Salinity affects plant growth because of osmotic stress, ionic stress, and nutritional imbalance (Ashraf and Harris, 2004; Munns and Tester, 2008). Osmotic stress affects growth immediately and is in saline soils caused by limitation of water uptake resulting from the high salt concentration in the soil. Ionic stress develops over time and is due to ion accumulation within the shoots. Osmotic stress accounts for roughly $75 \%$ of the biomass decrease under salt stress, and ionic stress reduces it by another 20\% (Munns and Tester, 2008). The strong effect of salinity on crop yield makes salinity tolerance in crops an important target for breeding. However, breeding for salt tolerance is not straightforward due to its genetic complexity.

Salt stress affects all the major processes underlying plant growth, including lipid and energy metabolism, photosynthesis, and protein synthesis (Parida and Das, 2005). This leads to reduction in transpiration, chlorophyll content, tiller number, and biomass (Hassanein, 1999; Chartzoulakis and Klapaki, 2000). The altered water status and unbalanced ion homeostasis resulting from saline conditions induce several mechanisms to reduce damage in the plant. Osmotic tolerance can be achieved by adapting water uptake properties of the roots, plant hydraulics, and by adjusting the plant's osmotic potential. Production of compatible solutes like proline (Khatkar and Kuhad, 2000), glycine betaine (Khan et al., 2000; Wang and Nii, 2000), sugars (Kerepesi and Galiba, 2000), and polyols (Bohnert et al., 1995; Zhifang and Loescher, 2003) facilitates osmotic adjustment or osmotic protection. To avoid toxic ion concentrations in shoots, plants exclude access sodium and chloride ions from the shoot. Bread wheat for instance has a low rate of $\mathrm{Na}^{+}$transport to the shoot and maintains a high ratio of $\mathrm{K}^{+} / \mathrm{Na}^{+}$in the leaves, which contributes to salt tolerance, while surum wheat is more saltsensitive due to its poor ability to exclude $\mathrm{Na}^{+}$from the shoot (Gorham et al., 1990). Shoot exclusion was shown to be facilitated by a members of the high-affinity $\mathrm{K}^{+}$transporter (HKT) family $(\mathrm{HKT} 1 ; 5)$ that can take $\mathrm{Na}^{+}$from the xylem into the parenchyma cells to minimize the accumulation of $\mathrm{Na}^{+}$in the shoot (Conde et al., 2011). Tissue tolerance to high salt concentrations is a mechanis often utilized by halophytes, and it can be achieved by compartmentalization of $\mathrm{Na}^{+}$and $\mathrm{Cl}^{-}$in cellular organelles like the vacuoles (Adams et al., 1992) and involves tonoplast $\mathrm{Na}^{+} / \mathrm{H}^{+}$ antiporters (NHX) that regulate cytosolic $\mathrm{Na}^{+}$concentration and pH (Bassil et al., 2012). In mature leaves, senescence may reflect the toxic effect of high levels of $\mathrm{Na}^{+}$concentration and low tissue tolerance to $\mathrm{Na}^{+}$(Munns and James, 2003). The combination of accumulation of $\mathrm{Na}^{+}$in leaves, lack of necrosis, and relatively little reduction of biomass can be indicative of tissue tolerance (Munns and James, 2003; Rajendran et al., 2009).
Salt stress not only affects the quantity but also the quality of Miscanthus biomass. Miscanthus genotypes with less ions in the harvestable biomass are particularly important because high concentrations of minerals can be corrosive to combustion equipment (Jorgensen, 1997). Thus, it is essential for Miscanthus to produce stable biomass with low ion concentrations under salt stress. Only few studies have been done in relation to salt tolerance of Miscanthus (Li et al., 2014; Plazek et al., 2014; Sun et al., 2014; Stavridou et al., 2016), and Miscanthus may be considered a moderately salt tolerant crop with salt concentrations higher than $100 \mathrm{mM} \mathrm{NaCl}$ (approximately 10 $\mathrm{dS} / \mathrm{m}$ ) reducing crop yields considerably. Until now the genetic diversity of salt tolerance in Miscanthus germplasm has not been investigated, although Sun et al. (2014) indicate that M. sinensis may harbor significant genetic variation for salt tolerance. The current study aims to explore genetic diversity of Miscanthus breeding material to identify genotypes for cultivation in saline soils, and genotypes that harbor salt tolerance traits and can serve as material for improvement of Miscanthus salt tolerance. The results showed that several genotypes with relatively high salt tolerance appeared to rely on different mechanisms, offering opportunities for breeding programs aimed at improved tolerance of Miscanthus.

\section{MATERIALS AND METHODS Plant Materials}

Seventy genotypes of Miscanthus were evaluated for salt tolerance (Table 1). The set included 57 M. sinensis, 5 M. sacchariflorus and eight hybrids (OPM-9 is Miscanthus $\times$ giganteus) and each genotype was cloned and propagated by tissue culture. The genotypes were supplied by different sources (Aberystwyth University, Institute for Agricultural and Fisheries Research ILVO, and Wageningen University \& Research). Two genotypes were tested in a pilot experiment to establish optimal experimental conditions.

\section{Pilot Experiment}

Two genotypes (OPM-13 and OPM-38) were grown under different levels of salinity $(0 \mathrm{mM}, 125 \mathrm{mM}$, and $250 \mathrm{mM}$ $\mathrm{NaCl})$. The seedlings were propagated in vitro, transferred to the hydroponics system and allowed to acclimate for 1 week. The hydroponics system consisted of containers $(22 \mathrm{~L}, 40 \mathrm{~cm}$ length, $30 \mathrm{~cm}$ width and $20 \mathrm{~cm}$ height) that can hold up to 12 Miscanthus plants. A maximum of 16 containers can be connected as a unit to a single reservoir, with capacity of 5001 nutrient solution. For the pilot experiment, three units were used for the three different salt levels, each with two connected containers. The nutrient solution was half-strength modified Hoagland's solution (Supplemental Table 1), maintained at pH 5.8 and refreshed weekly. Seedlings with four leaves were selected and transferred to the hydroponics containers. Each container had two genotypes in four replications (8 plants). After 1 week of acclimation, $\mathrm{NaCl}$ was added to the nutrient solutions of two of the units with a $25 \mathrm{mM}$ daily increment until a concentration of $125 \mathrm{mM} \mathrm{NaCl}$. Only one of those units received two more additions of $62.5 \mathrm{mM} \mathrm{NaCl}$ to reach $250 \mathrm{mM} \mathrm{NaCl}$. The average day/night temperatures were 
TABLE 1 | Miscanthus genotypes screened for salt tolerance.

\begin{tabular}{|c|c|c|}
\hline No. & Supplier & Genotype \\
\hline OPM-4 & IBERS & M. sacchariflorus \\
\hline OPM-5 & IBERS & Hybrid ( $M$. sinensis $\times M$. sacchariflorus) \\
\hline OPM-6 & IBERS & Hybrid (M. sacchariflorus $\times M$. sinensis) \\
\hline OPM-7 & IBERS & Hybrid (M. sacchariflorus $\times$ M. sinensis) \\
\hline OPM-8 & IBERS & Hybrid (M. sacchariflorus $\times M$. sinensis) \\
\hline OPM-9 & IBERS & Hybrid (Miscanthus $\times$ giganteus) \\
\hline OPM-10 & IBERS & Hybrid (M. sacchariflorus $\times$ M. sinensis) \\
\hline OPM-11 & IBERS & M. sinensis \\
\hline OPM $-13^{\star}$ & WUR & M. sinensis \\
\hline OPM-16 & IBERS & Hybrid (M. sacchariflorus $\times$ M. sinensis) \\
\hline OPM-19 & IBERS & M. sacchariflorus \\
\hline OPM-20 & IBERS & Hybrid (M. sacchariflorus $\times$ M. sinensis) \\
\hline OPM-24 & IBERS & M. sacchariflorus \\
\hline OPM-26 & IBERS & M. sacchariflorus \\
\hline OPM-30 & IBERS & M. sinensis \\
\hline OPM-31 & IBERS & M. sinensis \\
\hline OPM-32 & IBERS & M. sinensis \\
\hline OPM-33 & IBERS & M. sinensis \\
\hline OPM-34 & IBERS & M. sacchariflorus \\
\hline OPM-37 & WUR & M. sinensis \\
\hline OPM-38* & WUR & M. sinensis \\
\hline OPM-41 & WUR & M. sinensis \\
\hline OPM-42 & WUR & M. sinensis \\
\hline OPM-44 & WUR & M. sinensis \\
\hline OPM-45 & WUR & M. sinensis \\
\hline OPM-47 & WUR & M. sinensis \\
\hline OPM-48 & WUR & M. sinensis \\
\hline OPM-49 & WUR & M. sinensis \\
\hline OPM-50 & WUR & M. sinensis \\
\hline OPM-56 & WUR & M. sinensis \\
\hline OPM-57 & WUR & M. sinensis \\
\hline OPM-58 & WUR & M. sinensis \\
\hline OPM-59 & WUR & M. sinensis \\
\hline OPM-62 & WUR & M. sinensis \\
\hline OPM-64 & WUR & M. sinensis \\
\hline OPM-65 & WUR & M. sinensis \\
\hline OPM-66 & WUR & M. sinensis \\
\hline OPM-67 & WUR & M. sinensis \\
\hline OPM-68 & WUR & M. sinensis \\
\hline OPM-69 & WUR & M. sinensis \\
\hline OPM-71 & WUR & M. sinensis \\
\hline OPM-72 & WUR & M. sinensis \\
\hline OPM-73 & WUR & M. sinensis \\
\hline OPM-74 & WUR & M. sinensis \\
\hline OPM-75 & WUR & M. sinensis \\
\hline OPM-76 & WUR & M. sinensis \\
\hline OPM-77 & WUR & M. sinensis \\
\hline OPM-78 & WUR & M. sinensis \\
\hline OPM-79 & WUR & M. sinensis \\
\hline OPM-81 & IBERS & M. sinensis \\
\hline OPM-82 & WUR & M. sinensis \\
\hline
\end{tabular}

(Continued)
TABLE 1 | Continued

\begin{tabular}{|c|c|c|}
\hline No. & Supplier & Genotype \\
\hline OPM-83 & WUR & M. sinensis \\
\hline OPM-84 & WUR & M. sinensis \\
\hline OPM-86 & WUR & M. sinensis \\
\hline OPM-87 & WUR & M. sinensis \\
\hline OPM-88 & WUR & M. sinensis \\
\hline OPM-89 & WUR & M. sinensis \\
\hline OPM-90 & WUR & M. sinensis \\
\hline OPM-91 & WUR & M. sinensis \\
\hline OPM-92 & WUR & M. sinensis \\
\hline OPM-94 & WUR & M. sinensis \\
\hline OPM-96 & IBERS & M. sinensis \\
\hline OPM-97 & IBERS & M. sinensis \\
\hline OPM-98 & WUR & M. sinensis \\
\hline OPM-99 & WUR & M. sinensis \\
\hline OPM-100 & ILVO & M. sinensis \\
\hline OPM-101 & WUR & M. sinensis \\
\hline OPM-103 & WUR & M. sinensis \\
\hline OPM-104 & WUR & M. sinensis \\
\hline OPM-107 & WUR & M. sinensis \\
\hline OPM-108 & WUR & M. sinensis \\
\hline OPM-109 & IBERS & M. sinensis \\
\hline
\end{tabular}

The OPM code for the genotypes was used within the EU project OPTIMISC

IBERS, Institute of Biological, Environmental, and Rural Sciences; Aberystwyth University, UK; ILVO, The Institute for Agricultural and Fisheries Research, Belgium; WUR, Wageningen University \& Research; The Netherlands.

*in pilot experiment.

set at $25 / 18^{\circ} \mathrm{C}$, and the photoperiod regime was $16 \mathrm{~h}$ light and $8 \mathrm{~h}$ dark. Greenhouse environmental humidity was controlled at $70 \%$. Additional lighting $\left(100 \mathrm{Wm}^{-2}\right)$ was used when the incoming shortwave radiation was below $200 \mathrm{Wm}^{-2}$. After 2 weeks of salt treatment the shoot dry weight and $\mathrm{Na}^{+}$and $\mathrm{Cl}^{-}$ concentrations of the shoots were measured and evaluated.

\section{Main Experiment Design}

Seedlings from the 70 genotypes were propagated in vitro for 6 weeks, and allowed to form roots. Then they were transferred to the greenhouse and allowed to acclimate for 2 weeks on hydroponic containers in the greenhouse (Unifarm, Wageningen University \& Research). Uniform seedlings with four leaves were selected and transferred to the hydroponics system for evaluation. Four independently controlled hydroponics units were used; two units for control and the other two for the salt treatment (Supplemental Figure 1), and each unit consisted of 12 connected containers that could hold 12 plants. The hydroponics system was filled with half-strength modified Hoagland's solution. After 1 week in the hydroponics system, $\mathrm{NaCl}$ was added to two of the four units with a $50 \mathrm{mM}$ daily increment to bring the final concentration to $150 \mathrm{mM} \mathrm{NaCl}$. The experiment had a split plot design with four replicate plants per genotype per treatment. For this, the 70 genotypes and two dummy plants were randomly assigned to the plant positions in six containers as one replication. Two replications of 70 
genotypes were grown in 12 containers on each unit, to a total of four replications on two units per treatment. The nutrient solution was refreshed weekly and maintained at $\mathrm{pH}$ 5.8. The greenhouse conditions were similar to the pilot experiment.

\section{Assessment of Growth Traits}

During the experiment, data was collected for plant height, leaf expansion, and tiller number for all plants grown under control and saline conditions. Plant height was measured from the base of the plant to the tip of the highest leaf with a ruler at day 1, day 10 and day 17 after starting the stress treatment. Growth rate was taken as the growth in height per day, expressed as $\mathrm{cm} /$ day. This was calculated as the difference in plant height between two timepoints, divided by the number of days between the timepoints. To measure leaf expansion, the youngest leaf of each plant was marked at the beginning of salt treatment and the length of this leaf was measured three times, 1, 3, 5, and 7 days after starting the stress treatment. Leaf expansion rate was expressed as the average leaf length increase per day and calculated as the difference of the leaf lengths at day 7 and day 1 divided by the number of days between these measurements (expressed as $\mathrm{cm} /$ day). Leaf senescence was measured by visual scoring of all leaves of each plant 17 days after starting the salt treatment. Leaf senescence scale is from 1 to 9 according the percentage of senescence area $(1=$ no senescence, $3=$ senesced area $1-30 \%, 5=$ senesced area $30-60 \%, 7=$ senesced areas $60-90 \%, 9=$ senesced area $>90 \%$ ). At harvest, 17 days afer starting the stress treatment, all seedlings from the control and salt treatments were separated into shoots and roots. Plant shoot fresh weight was measured immediately at harvest. Both plant parts were dried separately in a forced-air oven at $70^{\circ} \mathrm{C}$ for 2 days, and the dry weight was measured.

\section{Ion Chromatography}

For determination of the ion concentrations in the shoots and roots of each genotype, four replicated samples per genotype were ground to fine powder using a hammer mill with $1 \mathrm{~mm}$ sieve following the protocol described by Nguyen et al. (2013). Dry leaf and root powders $(25 \pm 1 \mathrm{mg})$ were ashed at $575^{\circ} \mathrm{C}$ for $5 \mathrm{~h}$. Ashed samples were dissolved by shaking for $30 \mathrm{~min}$ in $1 \mathrm{ml} 3 \mathrm{M}$ formic acid at $99^{\circ} \mathrm{C}$ and then diluted with $9 \mathrm{ml}$ MiliQ water. The samples were shaken again at $80^{\circ} \mathrm{C}$ for another $30 \mathrm{~min}$. A final $500 \mathrm{x}$ dilution was subsequently prepared by mixing $0.2 \mathrm{ml}$ sample solution with $9.8 \mathrm{ml}$ MiliQ to assess the $\mathrm{Na}^{+}, \mathrm{K}^{+}, \mathrm{Cl}^{-}$, and $\mathrm{Ca}^{2+}$ content of each root and leaf sample using Ion Chromatography (IC) system 850 Professional, Metrohm (Switzerland).

\section{Statistical Analysis of Phenotypic Data}

Analysis of variance (ANOVA) was done in a split plot design using Genstat 15th version. The four hydroponics units contained four replicated whole plots (schematically represented in supplementary Figure 1). The whole plots were divided in two split plots of two adjacent units. The two treatments were assigned to one of the two units in a split plot. Each split plot contained six adjacent containers as a block (2 blocks per unit, and four blocks per treatment). Within each block, genotypes were randomly distributed. The growth rate and leaf expansion of each genotype in control and saline conditions were compared by student's $T$-test. Correlation coefficients (r) among all the parameters were calculated. All statistical analyses were performed using the statistical software package Genstat 15th edition (VSN International Hemel Hempstead, UK).

\section{RESULTS}

\section{Growth Responses to Salinity Stress}

In a pilot experiment, two genotypes (OPM-13 and OPM-38) were grown on hydroponics at three different salt conditions ( 0 , 125 , and $250 \mathrm{mM} \mathrm{NaCl}$ ). Growth of these Miscanthus genotypes was already affected at $125 \mathrm{mM}$ (Shoot Dry Weight was reduced by 24 and $68 \%$ for OPM-38 and OPM-13, respectively, and 36 and $63 \%$ at $250 \mathrm{mM} \mathrm{NaCl}$ ). At both salinity levels, $\mathrm{Na}^{+}$and $\mathrm{Cl}^{-}$concentrations of the shoots were significantly increased (Supplementary Table 2). The high salt concentration of 250 $\mathrm{mM}$ seriously damaged the seedlings, which may confound the physiological interpretation of ion concentration data in relation to ion homeostasis. We concluded that a salt stress of $150 \mathrm{mM}$ $\mathrm{NaCl}$ of the plants would affect growth of the plants considerably but inflict only limited damage. Therefore, we chose a salt stress level of $150 \mathrm{mM} \mathrm{NaCl}$ for identifying salt tolerant genotypes and traits contributing to salt tolerance.

The 70 genotypes showed a wide variation in response to 150 $\mathrm{mM} \mathrm{NaCl}$ salt treatment. There were significant differences in leaf expansion, growth rate, shoot fresh weight, shoot dry weight, root dry weight, root length, the number of leaves, and senescence score between the 70 genotypes $(P<0.001)$ and between control and salt treatment $(P<0.001)$ (Figures $1 \mathbf{A}-\mathbf{G})$. The reduction under saline conditions compared to control conditions for expansion of young leaves and growth rate in plant height was 27 and 54\%, respectively. The average shoot dry weight decreased by $58 \%$ from $1.83 \mathrm{~g}$ under control conditions to $0.77 \mathrm{~g}$ under salt stress conditions. The average root dry weight was also decreased but to a lesser extent, from $0.57 \mathrm{~g}$ in control conditions to $0.45 \mathrm{~g}$ under salt stress. The average number of leaves was reduced from 3.8 to 2.6 as a result of salt stress, and senescence was increased around 1.5 -fold at harvest in salt-stressed plants.

\section{Growth Rates}

The height of the salt treated plants was reduced $14-88 \%$ while the growth rate was decreased from 41 to $86 \%$ in the 70 genotypes. The growth rate of the seedlings was highly correlated to height both under salt $(r=0.81)$ and control conditions $(r=$ $0.94)$. This trait also showed significant correlation with shoot dry weight under salinity $(r=0.68)$ and control conditions $(r=0.76)$. The growth rate of 22 genotypes was not significantly different at early stages between control and salt conditions (Table 2).

\section{Leaf Expansion Rates}

The leaf expansion rate of the 70 genotypes was on average reduced by $27 \%$ from $2.67 \mathrm{~cm} /$ day under control conditions to $1.96 \mathrm{~cm} /$ day under saline conditions. Expansion rate of the second young leaf showed a more marked difference between the salt-treated and control seedlings than the flag leaf. There were significant effects for genotype $(p<0.001)$, treatment 


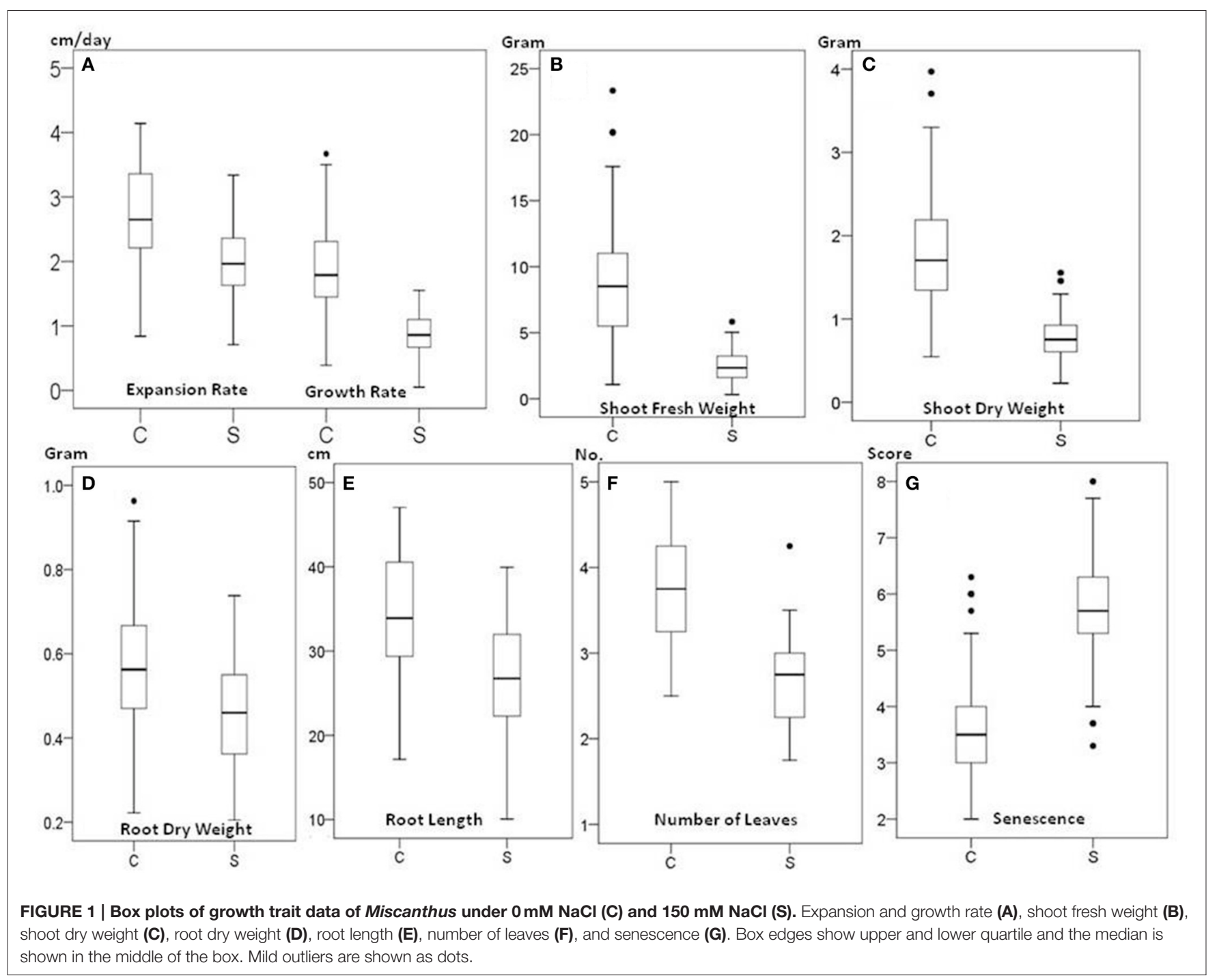

$(p<0.001)$ and genotype by treatment interaction $(p=0.004)$ for leaf expansion rate (Table 2). Expansion rate differences between control and salt-treated genotypes ranged from 3 to $48 \%$. In 46 genotypes, the leaf expansion under salt stress was not significantly different from control. Leaf expansion rate significantly correlated with shoot dry weight under salinity $(r=$ $0.86)$ and control conditions $(r=0.82)$.

\section{$\mathrm{Na}^{+}$Accumulation in Leaves}

The 70 genotypes showed large differences in leaf $\mathrm{Na}^{+}$ concentration of salt-stressed plants, from $4.25 \mathrm{mg} / \mathrm{g}$ in OPM-59 to $47.22 \mathrm{mg} / \mathrm{g}$ in OPM-47, and the $\mathrm{K}^{+} / \mathrm{Na}^{+}$ratio ranged from 5.39 in OPM-59 to 0.49 in OPM-47 (Figure 2, Supplementary Figure 2). Of the six genotypes with the highest $\mathrm{Na}^{+}$concentrations in the leaves (OPM-47, 49, 57, 66, 67, and 94), OPM-49 and 57 had a relatively high tiller number and low percentage of dead leaves and OPM-57 had slightly higher than average biomass (Table 3). This indicates that these genotypes may utilize a tissue tolerance mechanism, possibly by accumulation of $\mathrm{Na}^{+}$in vacuoles. On the other hand, some genotypes showed low shoot sodium concentrations under salt stress. Six genotypes (OPM-4, 32, 37, 59, 69, and 71) not only showed the lowest $\mathrm{Na}^{+}$concentration but also had the highest $\mathrm{K}^{+} / \mathrm{Na}^{+}$ratio in leaves. Additionally, these genotypes demonstrated less senescence on leaves compared with the high$\mathrm{Na}^{+}$genotypes, relatively high biomass, and low leaf $\mathrm{Na}^{+} /$root $\mathrm{Na}^{+}$ratio. This indicates that these genotypes may utilize a shoot exclusion mechanism under saline conditions. Among these, OPM-37 was relatively tolerant and it also had the highest biomass of all genotypes under saline conditions (Table 4).

\section{Ion Homeostasis Change to Salinity Stress}

The boxplots in Figures 3A,B show the genotypic variation of the ion contents in both shoots and roots under control and salt conditions. There were significant differences in the ion concentrations $(P<0.001)$ in shoots and roots of 70 genotypes under control and salt treatment $(P<0.001)$. The interaction between genotypes and treatments was significant 
TABLE 2 | Plant growth rate (plant height increase) and leaf expansion rate of leaves of miscanthus genotypes grown on hydroponics at $0 \mathrm{mM} \mathrm{NaCl}$ and $150 \mathrm{mM} \mathrm{NaCl}$.

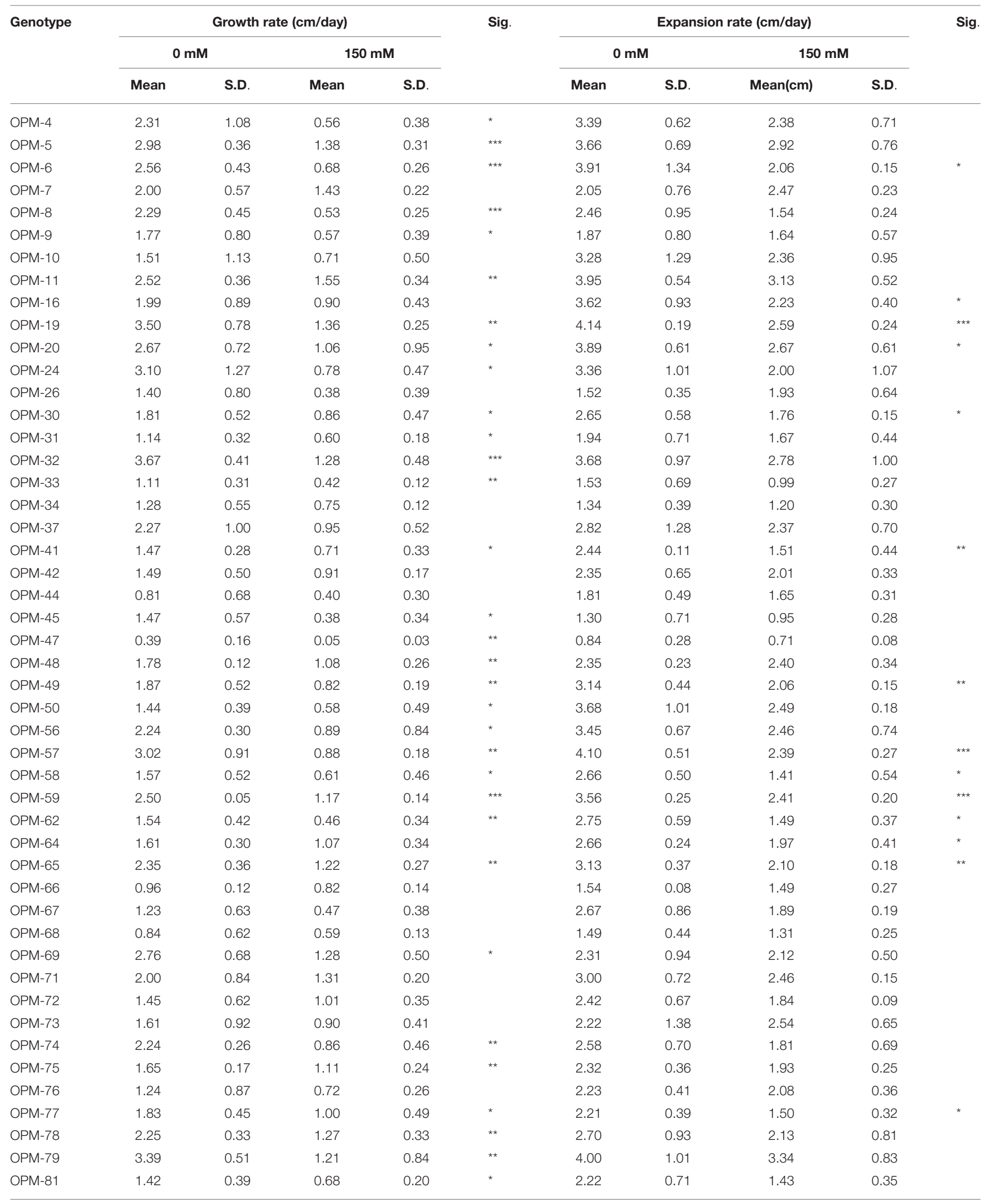


TABLE 2 | Continued

\begin{tabular}{|c|c|c|c|c|c|c|c|c|c|c|}
\hline \multirow[t]{3}{*}{ Genotype } & \multicolumn{4}{|c|}{ Growth rate (cm/day) } & \multirow[t]{3}{*}{ Sig. } & \multicolumn{4}{|c|}{ Expansion rate (cm/day) } & \multirow[t]{3}{*}{ Sig. } \\
\hline & \multicolumn{2}{|c|}{$0 \mathrm{mM}$} & \multicolumn{2}{|c|}{$150 \mathrm{mM}$} & & \multicolumn{2}{|c|}{$0 \mathrm{mM}$} & \multicolumn{2}{|c|}{$150 \mathrm{mM}$} & \\
\hline & Mean & S.D. & Mean & S.D. & & Mean & S.D. & Mean(cm) & S.D. & \\
\hline OPM-82 & 1.58 & 0.53 & 1.10 & 0.11 & & 2.65 & 0.22 & 2.09 & 0.26 & * \\
\hline OPM-83 & 1.35 & 0.48 & 0.88 & 0.16 & & 1.89 & 0.56 & 1.63 & 0.16 & \\
\hline OPM-84 & 1.96 & 0.36 & 1.07 & 0.20 & $\star \star$ & 2.85 & 0.41 & 2.31 & 0.12 & * \\
\hline OPM-86 & 1.80 & 0.20 & 0.83 & 0.28 & $\star \star \star ~$ & 2.39 & 0.61 & 1.81 & 0.39 & \\
\hline OPM-87 & 2.50 & 0.20 & 0.83 & 0.44 & $\star \star \star \star ~$ & 3.26 & 0.27 & 1.96 & 0.50 & ** \\
\hline OPM-88 & 2.10 & 0.86 & 0.89 & 0.34 & * & 2.63 & 1.21 & 1.91 & 0.53 & \\
\hline OPM-89 & 2.48 & 0.14 & 1.15 & 0.08 & $\star \star \star$ & 3.65 & 0.24 & 2.07 & 0.39 & $\star \star \star$ \\
\hline OPM-90 & 1.80 & 0.22 & 0.78 & 0.05 & $\star \star \star$ & 2.88 & 0.38 & 1.96 & 0.10 & $\star \star$ \\
\hline OPM-91 & 1.78 & 0.45 & 0.74 & 0.38 & * & 2.82 & 0.57 & 1.69 & 0.48 & * \\
\hline OPM-92 & 2.70 & 0.29 & 1.46 & 0.34 & 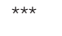 & 3.74 & 0.38 & 2.35 & 0.16 & $* \star *$ \\
\hline OPM-94 & 0.88 & 0.42 & 0.50 & 0.38 & & 0.94 & 0.58 & 0.87 & 0.30 & \\
\hline OPM-96 & 2.08 & 0.32 & 0.76 & 0.41 & ** & 3.29 & 0.27 & 1.72 & 0.52 & ** \\
\hline OPM-97 & 1.96 & 0.40 & 1.22 & 0.16 & * & 3.34 & 0.24 & 2.17 & 0.30 & 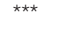 \\
\hline OPM-98 & 1.61 & 0.48 & 1.06 & 0.47 & & 2.24 & 0.82 & 1.84 & 0.25 & \\
\hline OPM-99 & 1.58 & 0.21 & 0.89 & 0.10 & $\star \star \star$ & 2.65 & 0.39 & 2.25 & 0.75 & \\
\hline OPM-100 & 1.76 & 0.40 & 0.78 & 0.49 & * & 1.61 & 0.56 & 1.37 & 0.41 & \\
\hline OPM-13 & 1.17 & 0.64 & 0.61 & 0.44 & & 2.18 & 0.32 & 1.62 & 0.39 & \\
\hline OPM-103 & 1.11 & 0.35 & 0.53 & 0.46 & & 1.56 & 0.43 & 1.20 & 0.24 & \\
\hline OPM-104 & 1.45 & 0.38 & 0.67 & 0.30 & * & 2.21 & 0.46 & 1.70 & 0.49 & \\
\hline OPM-107 & 3.00 & 0.27 & 1.14 & 0.36 & 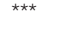 & 3.78 & 0.36 & 2.24 & 0.32 & 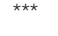 \\
\hline OPM-108 & 1.42 & 0.28 & 0.85 & 0.25 & * & 1.80 & 0.32 & 1.39 & 0.14 & \\
\hline OPM-109 & 2.90 & 0.59 & 1.54 & 0.47 & * & 3.51 & 0.95 & 2.41 & 0.59 & \\
\hline
\end{tabular}

${ }^{\star},{ }^{* *},{ }^{\star \star *}$, significant at $P<0.05 ; 0.01 ; 0.001$ respectively.

$(P<0.001)$ for both $\mathrm{Na}^{+}$and $\mathrm{Cl}^{-}$concentration under salt stress. In both shoots and roots, the $\mathrm{Na}^{+}$and $\mathrm{Cl}^{-}$concentrations increased significantly under salt stress $(P<0.001)$, while $\left[\mathrm{K}^{+}\right]$ and $\left[\mathrm{Ca}^{2+}\right]$ decreased at $150 \mathrm{mM} \mathrm{NaCl}$. In the leaves, $\mathrm{Na}^{+}$ and $\mathrm{Cl}^{-}$concentrations increased 4.6- and 3.1-fold under salt treatment, accumulating to $12.55 \mathrm{mg} / \mathrm{g}$ for $\mathrm{Na}^{+}$and $18.07 \mathrm{mg} / \mathrm{g}$ for $\mathrm{Cl}^{-}$(Figure 3A) but $\mathrm{K}^{+}$and $\mathrm{Ca}^{2+}$ concentrations in the shoots under saline conditions were 0.5 - and 0.6 -fold lower than those under control conditions. In the roots, $\mathrm{Na}^{+}$and $\mathrm{Cl}^{-}$concentrations showed 13- and 5-fold increases under salt treatment, respectively accumulating to $37.23 \mathrm{mg} / \mathrm{g}$ for $\mathrm{Na}^{+}$ and $19.66 \mathrm{mg} / \mathrm{g}$ for $\mathrm{Cl}^{-}$(Figure 3B) while both $\mathrm{K}^{+}$and $\mathrm{Ca}^{2+}$ concentrations decreased by $50 \%$ compared with those under control conditions. Under salt stress, $\mathrm{Na}^{+}$concentration in the roots was much higher than in shoots (3.6-fold), while $\mathrm{Cl}^{-}$ concentration in roots was slightly higher than in shoots (1.23fold). This indicates that these genotypes may have an active mechanism to keep the $\mathrm{Na}^{+}$concentration low in the shoots.

\section{Salt Tolerant Genotypes}

Salt tolerance was assessed as the percentage of shoot dry weight under saline relative to control conditions. The set of 70 genotypes grown at $150 \mathrm{mM} \mathrm{NaCl}$ in the hydroponic system showed large variation for salt tolerance, from $26 \%$ for OPM24 to $69 \%$ for OPM-31 (Figure 4, Supplementary Figure 3). Salt tolerance of the commercial genotype OPM-9 (Miscanthus $\times$ giganteus) was $42 \%$. The shoot dry weight in salt stress varied from 0.23 to $1.56 \mathrm{~g}$, and from 0.55 to $3.97 \mathrm{~g}$ under control conditions. The reduction in shoot dry weight ranged from 30 to $73 \%$. It is interesting to note that the genotypes with high salt tolerance (over $50 \%,<50 \%$ reduction in biomass) generally had relatively low biomass under control conditions. The top 10 genotypes for salt tolerance had less biomass ( $1.48 \mathrm{~g}$ ) compared to overall average $(1.83 \mathrm{~g}$ ) under control conditions but the biomass was slightly higher than average $(0.84$ vs. $0.77 \mathrm{~g})$ under salt stress (Supplementary Table 3). Those genotypes therefore were the most tolerant, but typically not the most productive under control conditions. The top 10 genotypes with high yield had on average more biomass under control conditions ( 2.99 vs. $1.83 \mathrm{~g}$ ) and more biomass compared to the overall average under salt stress ( 1.23 vs. $0.77 \mathrm{~g}$ ). These genotypes were still more productive under saline conditions, even if they were less tolerant to salinity (Supplementary Table 3). The genotype OPM-37 seemed to be interesting because it has the highest yield (1.56g) under salt stress, is among the higher producers ( $3.16 \mathrm{~g}$ ) under control conditions, and is relatively salt tolerant (49\%).

\section{Associations between Growth Traits and Salt}

Correlations between the different physiological traits and ion concentrations are given in Table 5. A highly significant negative 


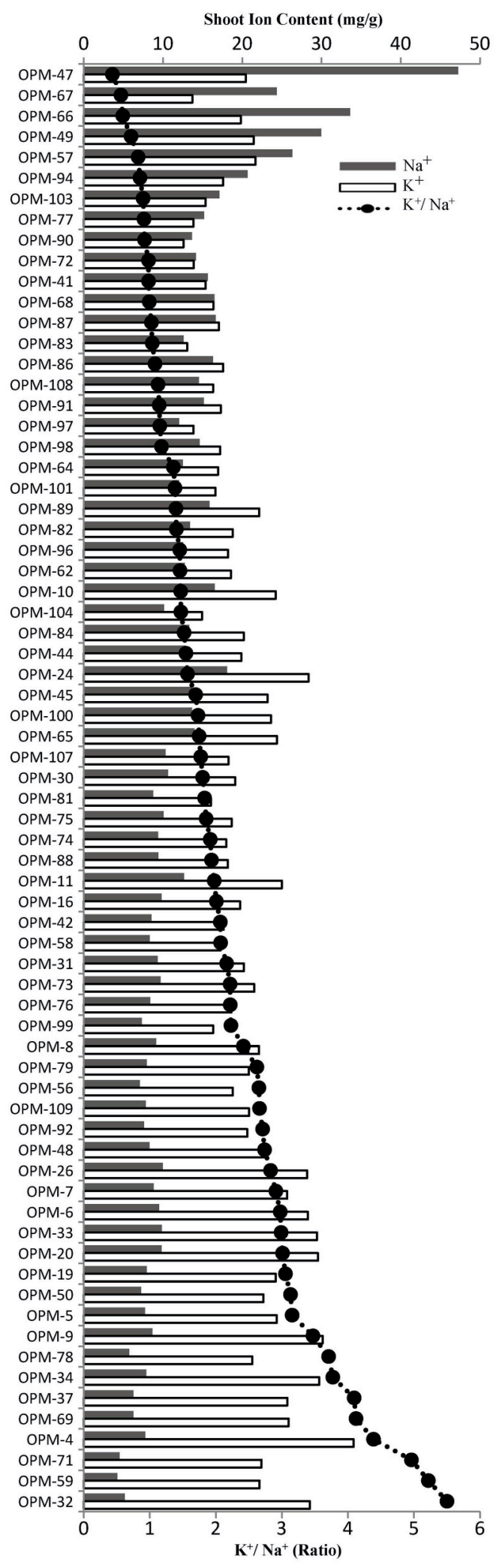

FIGURE 2 | Shoot $\mathrm{Na}^{+}$and $\mathrm{K}^{+}$concentration (gray and white bars, respectively) and shoot $\mathrm{K}^{+} / \mathrm{Na}^{+}$ratio (line-scatter plot) in leaves of 70 Miscanthus genotypes grown under saline conditions (150 mM NaCl). correlation of $\mathrm{Cl}^{-}$and $\mathrm{Na}^{+}$concentrations in shoots was found with growth traits (shoot dry weight, shoot fresh weight, root dry weight, and root length) under salt stress. Leaf $\mathrm{Cl}^{-}$and $\mathrm{Na}^{+}$ concentrations were negatively correlated $(P<0.001)$ to the shoot biomass ( $r=-0.43$ and -0.53 , respectively) at $150 \mathrm{mM}$ $\mathrm{NaCl}$. Under salt treatment, there was a high correlation between $\mathrm{Cl}^{-}$and $\mathrm{Na}^{+}$concentrations in both leaves $(r=0.94)$ and roots $(r=0.66)$ but under control conditions there was only a weak correlation in leaves $(r=0.26)$ and no significant correlation in roots. The shoot dry weight was positively correlated with leaf expansion rate, root dry weight, growth rate, and root length under salt stress $(r=0.86,0.85,0.68$, and 0.62 , respectively). The correlation between $\mathrm{K}^{+}$and $\mathrm{Na}^{+}$concentrations in leaves and roots were not significant under salt stress while there was weak correlation for these traits in both leaves $(r=0.48)$ and roots $(r=$ 0.44 ) under control conditions. However, the $\mathrm{K}^{+}$concentration in leaves was positively correlated with shoot fresh weight $(r=$ $0.41)$ and weakly correlated with shoot dry weight $(r=0.30)$ at $150 \mathrm{mM} \mathrm{NaCl}$, similar to the correlations at $0 \mathrm{mM} \mathrm{NaCl}(r=0.4$ and 0.28 , respectively). The ratio of $\mathrm{K}^{+} / \mathrm{Na}^{+}$was positively $(P<$ $0.001)$ related to the shoot biomass $(r=0.56)$ in all genotypes under salt treatments but it was weak $(r=0.31)$ under control conditions.

\section{DISCUSSION}

Bioenergy crops are an important alternative to fossil fuel, and a valuable addition to other alternative forms of energy (Brosse et al., 2012). Growing these crops on underutilized, marginal soils like saline soils would avoid competition with food crops for agricultural land. The potential for improvement of Miscanthus for salinity tolerance still remains to be established, as most research has focused only on Miscanthus $\times$ giganteus (Plazek et al., 2014; Stavridou et al., 2016) and genetic diversity for salinity tolerance of Miscanthus germplasm is largely unknown. The current study evaluated seventy Miscanthus genotypes under salt stress and showed that broad diversity for salt tolerance and salt tolerance traits is present in Miscanthus. Several highly salt tolerant genotypes utilizing different mechanisms can be considered as valuable breeding material.

\section{Screening System}

A reliable screening system for salt tolerance traits is essential, as uniform exposure of plants to salt stress is hard to establish and control in field experiments (Munns and James, 2003; Almeida et al., 2016). Hydroponic systems supply uniform conditions for the root environment, and have a high capacity of genotypes at the same time (Nguyen et al., 2013; Chan-Navarrete et al., 2014). Using such a system, traits, and QTLs contributing to variation in salt tolerance in barley were already successfully identified (Long et al., 2013; Nguyen et al., 2013), and to variation in nitrogen use efficiency in spinach (Chan-Navarrete et al., 2016). It is important to keep in mind however that factors like soil texture and composition that in the field also may influence salinity tolerance do not play a role in this type of system. Also, root properties related to soil traits and exploration 
TABLE 3 | Trait comparisons of 6 Miscanthus genotypes with high leaf $\mathrm{Na}^{+}$ion concentrations under salt stress, grown at $150 \mathrm{mM} \mathrm{NaCl}$ on hydroponics.

\begin{tabular}{|c|c|c|c|c|c|c|c|}
\hline Genotype & OPM-47 & OPM-49 & OPM-57 & OPM-66 & OPM-67 & OPM-94 & Average of 70 genotypes \\
\hline Tiller number & 0 & 2.25 & 2 & 1.25 & 2.25 & 0 & 1.73 \\
\hline Dead leaves (\%) & 50 & 32 & 35 & 40 & 40 & 56 & 28 \\
\hline 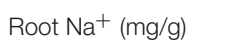 & 56.5 & 32.85 & 33.33 & 50.99 & 34.58 & 29.81 & 37.23 \\
\hline Leaf K+ (mg/g) & 20.45 & 21.44 & 21.66 & 19.81 & 13.69 & 17.58 & 20.67 \\
\hline $\mathrm{K}^{+} / \mathrm{Na}^{+}$in leaf & 0.43 & 0.71 & 0.82 & 0.59 & 0.56 & 0.85 & 2.08 \\
\hline Leaf $\mathrm{Na}^{+} / \mathrm{Root} a^{+}$ & 0.84 & 0.92 & 0.79 & 0.66 & 0.70 & 0.69 & 0.34 \\
\hline
\end{tabular}

TABLE 4 | Trait comparisons of 6 Miscanthus genotypes with low leaf $\mathrm{Na}^{+}$concentrations under salt stress, grown at $150 \mathrm{mM}$ NaCl on hydroponics.

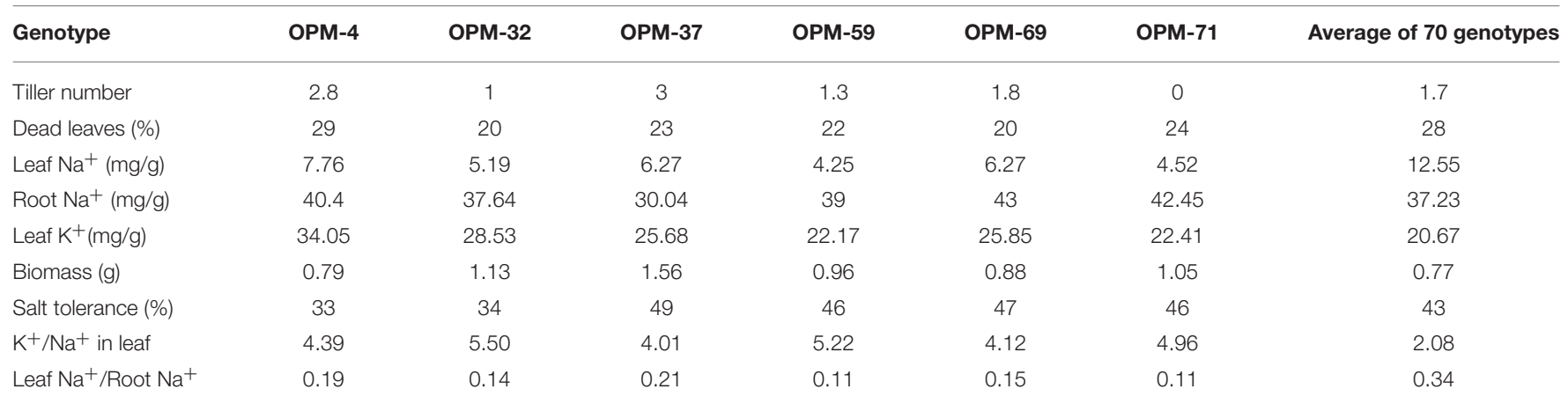

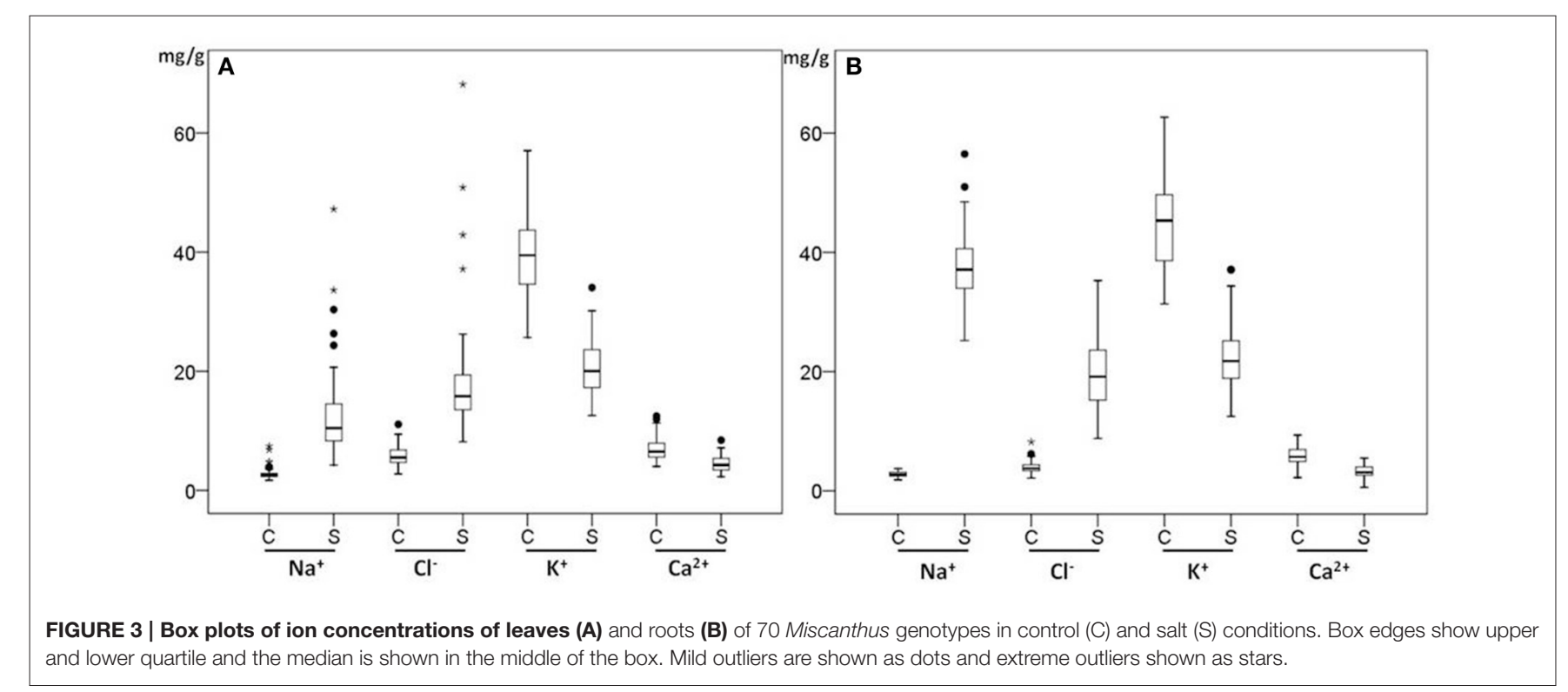

of the soil will have a different impact on growth and yield. Another limitation of hydroponics evaluation is that it only allows screening of relatively young plants. Nevertheless, given the difficulty to maintain uniform screening conditions in a large population in the field (Tavakkoli et al., 2012), hydroponics provides a highly useful alternative. It is a fast and uniform way to identify high potential genotypes with interesting salt tolerance traits that particularly relate to ion homeostasis and other cellular tolerance mechanisms, like osmotic adjustment and scavenging of reactive oxygen species (ROS). Indeed, several studies on salt tolerance using hydroponics systems found correlations between salt tolerance and $\mathrm{Na}^{+}$and $\mathrm{K}^{+}$concentrations in shoot (Munns and James, 2003; Jaarsma et al., 2013; Platten et al., 2013). Similarly, we identified several salt tolerant genotypes in our hydroponics-based screening with low $\mathrm{Na}^{+}$concentrations in the leaves (Table 4). These are likely to utilize $\mathrm{Na}^{+}$exclusion 
TABLE 5 | Pearson correlations between the traits under salt stress (left lower triangle) and control (right upper triangle).

\begin{tabular}{|c|c|c|c|c|c|c|c|c|c|c|c|c|c|c|c|c|c|c|c|}
\hline & $\begin{array}{l}\mathrm{Cl}^{-} \\
\text {leaf }\end{array}$ & $\begin{array}{l}\mathrm{Na}^{+} \\
\text {leaf }\end{array}$ & $\begin{array}{l}\mathrm{K}^{+} \\
\text {leaf }\end{array}$ & $\begin{array}{c}\mathrm{Cl}^{-} \\
\text {root }\end{array}$ & $\begin{array}{l}\mathrm{Na}^{+} \\
\text {root }\end{array}$ & $\begin{array}{l}\mathrm{K}^{+} \\
\text {root }\end{array}$ & $\begin{array}{c}\mathrm{K}^{+} / \mathrm{Na}^{+} \\
\text {leaf }\end{array}$ & $\begin{array}{c}\mathrm{K}^{+} / \mathrm{Na}^{+} \\
\text {root }\end{array}$ & Exp & GR & Height & SFW & SDW & RDW & RL & $\begin{array}{l}\text { Tiller } \\
\text { No. }\end{array}$ & $\begin{array}{l}\text { Leaf } \\
\text { No. }\end{array}$ & Sen & DL \\
\hline $\begin{array}{l}\mathrm{Cl}^{-} \\
\text {leaf }\end{array}$ & 0.09 & 0.26 & 0.76 & -0.09 & 0.31 & 0.00 & 0.26 & -0.24 & 0.20 & 0.52 & 0.44 & 0.45 & 0.35 & 0.09 & 0.28 & 0.13 & 0.63 & 0.01 & 0.21 \\
\hline $\mathrm{Na}^{+}$ & 0.94 & 0.01 & 0.48 & -0.21 & 0.20 & 0.17 & -0.47 & -0.08 & -0.07 & 0.03 & 0.00 & -0.02 & -0.09 & -0.09 & 0.04 & -0.12 & 0.22 & -0.04 & 0.05 \\
\hline $\begin{array}{l}\mathrm{K}^{+} \\
\text {leaf }\end{array}$ & 0.00 & -0.23 & 0.69 & -0.26 & 0.31 & 0.20 & 0.18 & -0.12 & 0.18 & 0.44 & 0.34 & 0.40 & 0.28 & 0.07 & 0.20 & 0.19 & 0.56 & 0.08 & 0.23 \\
\hline $\begin{array}{c}\mathrm{Cl}^{-} \\
\text {root }\end{array}$ & 0.25 & 0.11 & 0.31 & 0.14 & 0.11 & 0.05 & -0.15 & -0.09 & -0.13 & -0.24 & -0.26 & -0.22 & -0.19 & -0.04 & -0.10 & -0.22 & -0.25 & 0.18 & 0.21 \\
\hline $\begin{array}{l}\mathrm{Na}^{+} \\
\text {root }\end{array}$ & 0.37 & 0.26 & 0.13 & 0.66 & 0.23 & 0.44 & -0.04 & -0.55 & 0.09 & 0.26 & 0.20 & 0.17 & 0.11 & 0.01 & 0.04 & 0.02 & 0.12 & 0.00 & 0.10 \\
\hline $\begin{array}{c}\mathrm{K}^{+} \\
\text {root }\end{array}$ & -0.13 & -0.16 & 0.28 & 0.37 & 0.07 & 0.29 & -0.05 & 0.44 & -0.17 & -0.04 & -0.11 & -0.09 & -0.10 & -0.04 & -0.14 & 0.06 & -0.07 & 0.17 & 0.14 \\
\hline $\begin{array}{c}\mathrm{K}^{+} / \mathrm{Na}^{+} \\
\text {leaf }\end{array}$ & -0.43 & -0.65 & 0.67 & 0.20 & 0.02 & 0.24 & 0.14 & 0.13 & 0.21 & 0.39 & 0.33 & 0.35 & 0.31 & 0.12 & 0.06 & 0.28 & 0.23 & -0.03 & -0.04 \\
\hline $\begin{array}{c}\mathrm{K}^{+} / \mathrm{Na}^{+} \\
\operatorname{root}\end{array}$ & -0.24 & -0.20 & 0.15 & -0.03 & -0.48 & 0.82 & 0.16 & -0.01 & -0.19 & -0.21 & -0.21 & -0.16 & -0.12 & -0.05 & -0.17 & 0.11 & -0.06 & 0.11 & 0.02 \\
\hline Exp & -0.35 & -0.43 & 0.28 & -0.21 & -0.20 & 0.01 & 0.48 & 0.06 & 0.80 & 0.74 & 0.85 & 0.81 & 0.82 & 0.81 & 0.60 & 0.49 & 0.35 & 0.03 & -0.05 \\
\hline GR & -0.48 & -0.51 & 0.16 & -0.09 & -0.19 & 0.19 & 0.44 & 0.22 & 0.74 & 0.73 & 0.94 & 0.83 & 0.76 & 0.53 & 0.47 & 0.34 & 0.61 & -0.04 & -0.01 \\
\hline Height & -0.45 & -0.52 & 0.25 & -0.21 & -0.22 & 0.01 & 0.49 & 0.06 & 0.95 & 0.81 & 0.87 & 0.90 & 0.86 & 0.66 & 0.55 & 0.42 & 0.61 & -0.03 & -0.04 \\
\hline SFW & -0.37 & -0.48 & 0.41 & -0.08 & -0.12 & 0.14 & 0.57 & 0.13 & 0.84 & 0.73 & 0.88 & 0.88 & 0.98 & 0.74 & 0.56 & 0.52 & 0.66 & -0.02 & -0.03 \\
\hline SDW & -0.43 & -0.53 & 0.30 & -0.17 & -0.18 & 0.01 & 0.56 & 0.05 & 0.86 & 0.68 & 0.90 & 0.92 & 0.85 & 0.80 & 0.59 & 0.53 & 0.61 & -0.02 & -0.06 \\
\hline RDW & -0.42 & -0.47 & 0.09 & -0.20 & -0.19 & 0.04 & 0.40 & 0.08 & 0.81 & 0.65 & 0.83 & 0.80 & 0.85 & 0.81 & 0.73 & 0.38 & 0.27 & 0.00 & -0.11 \\
\hline $\mathrm{RL}$ & -0.34 & -0.34 & -0.03 & -0.18 & -0.18 & -0.16 & 0.23 & -0.11 & 0.61 & 0.60 & 0.70 & 0.59 & 0.62 & 0.72 & 0.72 & 0.21 & 0.36 & -0.01 & -0.03 \\
\hline $\begin{array}{c}\text { Tiller } \\
\text { No. }\end{array}$ & -0.18 & -0.20 & 0.16 & -0.44 & -0.35 & -0.29 & 0.11 & -0.09 & 0.46 & 0.19 & 0.44 & 0.39 & 0.44 & 0.37 & 0.40 & 0.45 & 0.31 & 0.12 & 0.07 \\
\hline $\begin{array}{l}\text { Leaf } \\
\text { No. }\end{array}$ & -0.18 & -0.32 & 0.48 & 0.07 & 0.13 & 0.10 & 0.42 & 0.00 & 0.29 & 0.29 & 0.32 & 0.47 & 0.35 & 0.22 & 0.28 & 0.25 & 0.68 & -0.01 & 0.09 \\
\hline Sen & 0.41 & 0.54 & -0.33 & -0.16 & 0.15 & -0.27 & -0.59 & -0.27 & -0.25 & -0.33 & -0.30 & -0.33 & -0.29 & -0.27 & -0.22 & -0.06 & -0.13 & 0.12 & 0.89 \\
\hline $\mathrm{DL}$ & 0.55 & 0.69 & -0.32 & 0.08 & 0.15 & -0.12 & -0.61 & -0.11 & -0.49 & -0.49 & -0.55 & -0.57 & -0.56 & -0.52 & -0.41 & -0.32 & -0.47 & 0.78 & 0.19 \\
\hline
\end{tabular}

The left upper to right lower corner diagonal indicates the correlation between trait values for control and saline conditions.

Sen, Senescence; DL, Dead leaves; Exp, Expansion rate; GR, Growth rate; SFW, Shoot Fresh Weight; SDW, shoot dry weight; RDW, Root dry weight; RL, Root length.

From light red to dark red, increasingly more positive correlation. From light blue to dark blue, increasingly more negative correlation.

mechanisms and may be useful genitors for salinity tolerance breeding programs. OPM-37 was even among the highest biomass producers both under control and salt conditions, and should be evaluated under field conditions as a potential high producing genotype on saline soils.

\section{Mechanisms and Useful Traits}

When grown in saline soils, plants are exposed to osmotic stress and ionic stress (Ashraf and Harris, 2004; Munns and Tester, 2008). Since osmotic and ionic stress both decrease yield and growth rate, improving salt tolerance in crops needs to take into account both osmotic tolerance and ion exclusion (Genc et al., 2010). Osmotic tolerance appears to contribute more to salt tolerance than avoiding ion toxicity in cultivated wheat and in barley (Rengasamy, 2010a). Leaf expansion is considered a good indicator for osmotic tolerance (Rajendran et al., 2009; Farouk, 2011). In our tested Miscanthus genotypes, leaf expansion showed highly significant correlation with shoot dry weight $(r=0.86)$ under salinity. The relatively high variation in the leaf expansion measurements may be caused by the relatively high variation in youngest leaf length between replicates of a genotype at the start of the measurements. This may be avoided by using more replicate plants and selecting only the plants with youngest leaves of comparable lengths, but that would require either a higher capacity (number of plants) of plants, or a reduction in the number of genotypes. 


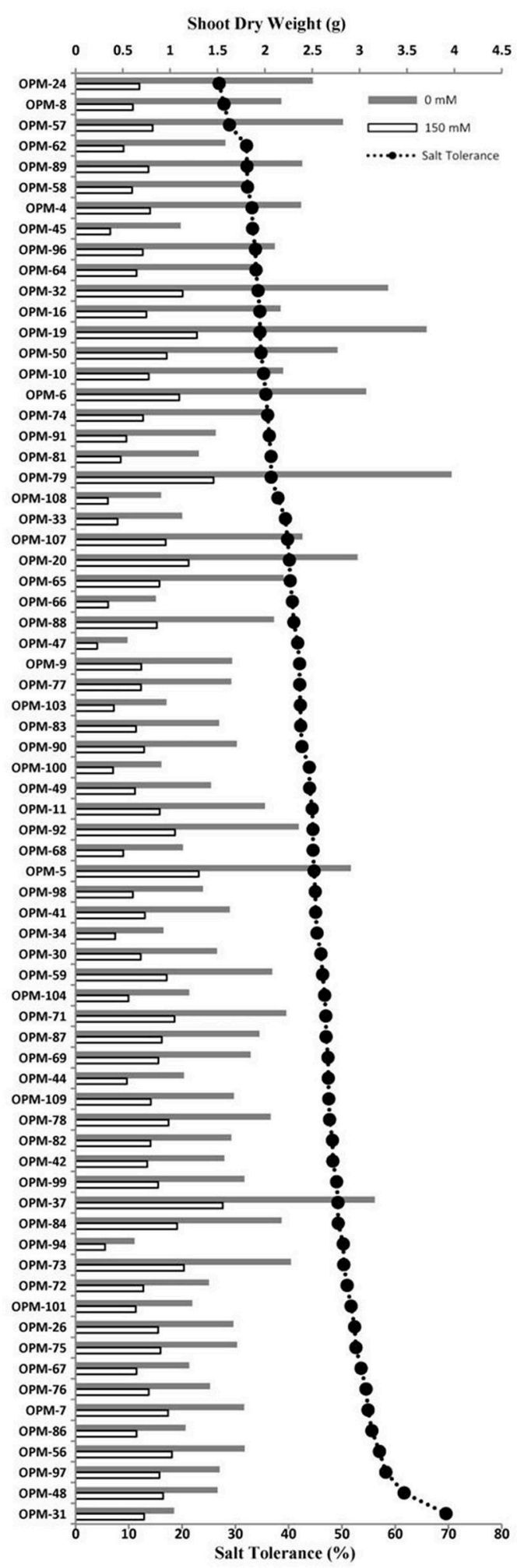

FIGURE 4 | Shoot dry weight (bars) and salt tolerance (line-scatter plot, calculated as the ratio of shoot dry weight under salt stress and shoot dry weight under control conditions) of 70 genotypes of Miscanthus grown in a hydroponics system at $0 \mathrm{mM} \mathrm{NaCl}$ (gray bars) and $150 \mathrm{mM}$ $\mathrm{NaCl}$ (white bars).
The most likely candidate genotypes to have osmotic tolerance may be the ones that have both limited reduction in both leaf expansion rate and in growth rate at early stages of the stress. Forty-six of the Miscanthus genotypes evaluated in this study showed no significant difference in expansion rate and 22 genotypes had no significant difference in growth rate as a result of salt stress (Table 2). Nineteen genotypes (OPM-7, 10, 26, 34, $37,42,44,66,67,68,71,72,73,76,83,94,98,13$, and 103) had both little reduction of leaf expansion and height, which would imply that more than $25 \%$ of the tested genotypes may have some level of osmotic tolerance that minimizes the early effects of salinity.

Ion toxicity is induced by prolonged salinity due to the accumulation of ions in plant tissues, especially in the leaves (Munns and James, 2003). The leaf blades are more sensitive to ion toxicity than the roots, so adapting ion homeostasis to keep a relatively low $\mathrm{Na}^{+}$concentration in the leaf is important (Munns and Tester, 2008). Under salt stress, high $\mathrm{Na}^{+}$concentrations interfere with $\mathrm{K}^{+}$uptake and $\mathrm{K}^{+}$function (Shabala and Cuin, 2008). Maintaining a high $\mathrm{K}^{+}$concentration at relatively high $\mathrm{Na}^{+}$levels is therefore another important mechanism under salt stress, and the $\mathrm{K}^{+} / \mathrm{Na}^{+}$ratio is considered an indicator of salt tolerance (Munns and James, 2003; Krishnamurthy et al., 2007). In a large-scale screen of 69 barley cultivars, $90 \%$ of the genotypes used an active $\mathrm{K}^{+}$maintenance mechanism to retain cytosolic $\mathrm{K}^{+}$concentrations, while $10 \%$ achieved this indirectly by efficiently excluding $\mathrm{Na}^{+}$from shoot (Chen et al., 2007; Schmer et al., 2008). In our evaluation, the $\mathrm{K}^{+} / \mathrm{Na}^{+}$ratio was not only positively correlated $(r=0.56)$ to shoot dry weight in the 70 tested genotypes, but also negatively correlated $(r=-0.59)$ to senescence under salt stress. Only 12 of the 70 genotypes had a $\mathrm{K}^{+} / \mathrm{Na}^{+}$ratio of $<1$ (Figure 2), indicating that most Miscanthus genotypes were able to maintain a relatively high $\mathrm{K}^{+}$ concentration compared to the $\mathrm{Na}^{+}$concentration.

Six genotypes with a high $\mathrm{K}^{+} / \mathrm{Na}^{+}$ratio (more than twice the average value) had low $\mathrm{Na}^{+}$concentrations in the leaves (Table 4). Low $\mathrm{Na}^{+}$concentration in the shoots was successfully used as selection criteria to breed for salt tolerant cultivars in wheat, barley and rice (Lin et al., 2004; Lindsay et al., 2004; Xue et al., 2009; Genc et al., 2010; Thomson et al., 2010; Munns et al., 2012). We identified a number of genotypes with low $\mathrm{Na}^{+}$ concentrations in the shoot and high salt tolerance, suggesting that these utilize $\mathrm{Na}^{+}$exclusion mechanisms similar to those used for improving salt tolerance in cereals. The genotypes with the lowest $\mathrm{Na}^{+}$concentrations in leaves also showed the lowest $\mathrm{Na}^{+}$shoot/ $\mathrm{Na}^{+}$root ratio (Table 4) implying that $\mathrm{Na}^{+}$is actively excluded from the shoots. The gene underlying the $\mathrm{Na}^{+}$ exclusion introduced from wild relatives in both rice and wheat was shown to be a member of the $\mathrm{Na}^{+}$-selective transporter HKT gene family. This HKT1;5 gene is expressed in parenchyma cells aligning the xylem in roots, and the HKT1;5 transporter was shown to filter $\mathrm{Na}^{+}$out of the xylem, thus preventing transport $\mathrm{Na}^{+}$from the roots to the shoots (Maser et al., 2002; Husain et al., 2003). Seven major and three minor alleles of OsHKT1;5 were identified in rice and the leaf $\mathrm{Na}^{+}$concentration was highly associated with $H K T 1 ; 5$ allelic variation across diverse accessions (Platten et al., 2013). It is not unlikely that a Miscanthus 
HKT1;5 ortholog is responsible for the variation in $\mathrm{Na}^{+}$shoot concentration in Miscanthus. It would therefore be worthwhile to study allelic variation and activity of this Miscanthus HKT1;5 ortholog under saline conditions in Miscanthus genotypes.

Because electrochemical balance is vital under stress, $\mathrm{Cl}^{-}$ and $\mathrm{Na}^{+}$uptake are often linked (Teakle and Tyerman, 2010). However, the $\mathrm{Na}^{+}$and $\mathrm{Cl}^{-}$exclusion mechanisms are independent, with different genotypes having different mechanisms to regulate $\mathrm{Na}^{+}$or $\mathrm{Cl}^{-}$transport (Teakle and Tyerman, 2010). For example, genotypes of Glycine max were more sensitive to $\mathrm{Cl}^{-}$ion accumulation, but G. soja genotypes were more sensitive to high levels of $\mathrm{Na}^{+}$ions (Luo et al., 2005). In our Miscanthus genotypes, the average $\mathrm{Cl}^{-}$root/shoot ratio was 1.23 but the $\mathrm{Na}^{+}$root/shoot ratio was 3.6 under salt treatment over 70 genotypes (Figure 3 ). This indicates that an active mechanism to avoid accumulation of $\mathrm{Na}^{+}$in the leaves is relatively abundant in Miscanthus, and a similar mechanism for $\mathrm{Cl}^{-}$ion accumulation in the shoots is much less prevalent. Nevertheless, there was a high correlation $(r=0.94)$ between $\mathrm{Cl}^{-}$and $\mathrm{Na}^{+}$concentrations in leaves and both $\mathrm{Cl}^{-}$and $\mathrm{Na}^{+}$ had negative correlations with shoot dry weight stress, $r=$ -0.43 and $r=-0.53$ respectively (Table 5). It is interesting that four genotypes (OPM-59, 71, 78, and 109) showed low $\mathrm{Cl}^{-}$ concentrations $(8.14-10.09 \mathrm{mg} / \mathrm{g})$ compared with the average $(18.06 \mathrm{mg} / \mathrm{g})$ in leaves as well as a relatively high $\mathrm{Cl}^{-}$root/shoot ratio (0.41-0.49) compared with the average (0.98). Those genotypes may have $\mathrm{Cl}^{-}$exclusion mechanisms (Supplementary Table 4).

In the present study, two genotypes (OPM-49 and 57) also showed more tillers and less senescence even with having high shoot concentrations of $\mathrm{Na}^{+}$and $\mathrm{Cl}^{-}$. This may be indicative for a tissue tolerance mechanism, with $\mathrm{Na}^{+}$and $\mathrm{Cl}^{-}$compartmentalized into the vacuoles to avoid toxic concentrations within the cytoplasm (Munns and James, 2003).

\section{Rhizome}

Root traits studied in a hydroponic system may not be representative for root characteristics in the soil and the effect these have on yield (Tavakkoli et al., 2012). For a perennial with a rhizome, like Miscanthus, this may be even more true. Chinese ryegrass Leymus chinensis can adapt to salt stress by accumulating $\mathrm{Na}^{+}$in the rhizome (Mann et al., 2013; Li et al., 2014). A similar result was found for Miscanthus $\times$ giganteus in a pot experiment; the $\mathrm{Na}^{+}$concentration in rhizomes was 3-fold higher in the rhizome than that in shoot under $150 \mathrm{mM} \mathrm{NaCl}$, and plants with larger rhizomes were more tolerant than plants with small rhizomes, with lower decreases in shoot dry weight under salinity (Plazek et al., 2014). This indicates that rhizomes may play an important role in salt tolerance of perennial grasses, and obviously this component of salt tolerance cannot be tested on a hydroponics system. However, keeping the limitations of the hydroponics system in mind, the advantages in terms of uniformity of plants and environmental conditions, as discussed before, can be exploited. We have shown here that identification of genetic variation for salt tolerance traits, and of mechanisms utilized by Miscanthus to counteract the effect of salinity can be done effectively on a hydroponics system. A selection of genotypes with varying salt tolerance properties could thus be made, and these can be used to study salt tolerance mechanisms in more detail in soil-grown plants in pots or in the field.

\section{Preferred Genotypes}

Although Miscanthus $\times$ giganteus with its high yield is the most popular commercial genotype, it has several disadvantages. Firstly, its tolerance to abiotic stress is not as high as M. sinensis (Clifton-Brown et al., 2001). With respect to chilling tolerance, the rhizomes of Miscanthus $\times$ giganteus cannot survive below approximately $-3^{\circ} \mathrm{C}$ but the hybrids of $M$. sinensis still live below $-4.5^{\circ} \mathrm{C}$ (Clifton-Brown and Lewandowski, 2000). Shoot dry weight of Miscanthus $\times$ giganteus in pots was reduced by $50 \%$ after 64 days at $120 \mathrm{mM} \mathrm{NaCl}$ (Stavridou et al., 2016), while $M$. sinensis accessions exhibited $<40 \%$ reduction under the same levels of salt stress (Sun et al., 2014). In our experiment, the reduction of Miscanthus $\times$ giganteus $(\mathrm{OPM}-9)$ at $150 \mathrm{mM} \mathrm{NaCl}$ for 2 weeks was $57 \%$, which was identical to the average salt tolerance in 70 genotypes. This offers opportunities for selecting and breeding genotypes that surpass Miscanthus $\times$ giganteus in salt tolerance and growth on marginal, saline soils. OPM-37 for instance had the highest yield under salt stress, and OPM-31 the lowest reduction compared to yield under control conditions. The hybrids OPM-5 (M. sinensis $\times$ M. sacchariflorus), and OPM7 (M. sacchariflorus $\times$ M. sinensis) used in our study had higher yield than Miscanthus $\times$ giganteus under control and salt stress as well as higher salt tolerance. These genotypes may be favorable choices for producing biomass on saline lands, and also may indicate the potential of new hybrids that combine favorable traits identified in this study. Lewandowski et al. (2016) indicated that OPM-5 and OPM-7 in a multi-location trial were not among the highest biomass producers under non-saline conditions. Whether these genotypes will be relatively good performers on saline soils remains to be established. Several genotypes had relatively high yields under both control and saline conditions, and may be preferred in soils with varying levels of salinity. These include OPM-5, OPM-6, OPM-19, OPM-20, OPM-32, OPM-37, and OPM-79. Among these seven genotypes, OPM-37, and OPM-5 have salt tolerance of $49 \%$ and $44 \%$, respectively, just above the average (43\%). These two genotypes may show osmotic mechanisms with limited reduction of the expansion rate. OPM-37 and OPM-5 had a less than average reduction in tiller number due to salt stress, and above average tiller number (3 and 3.25 respectively, while average tiller number was 1.7) under salt stress. These two genotypes have relatively high potential to be cultivated on marginal lands.

It is important to take into account how Miscanthus quality is used for bioenergy when choosing optimal genotypes for growth under saline conditions, or genitors for breeding programs. A low ion content of harvested material is very important for combustion quality because the high mineral content can reduce the ash melting point and cause corrosion issues, especially $\mathrm{K}^{+}$ and $\mathrm{Cl}^{-}$(Brosse et al., 2012). Jorgensen (1997) showed that during harvest season (spring) the $\mathrm{K}^{+}$and $\mathrm{Cl}^{-}$concentrations in $M$. sinensis were reduced by $85-95 \%$ in the normal field because of relocation of minerals to storage organs and leaching by rain. However, the potential impact on combustion properties 
for material grown on saline lands is largely unknown. Whether the ions accumulate in the senesced stem that is harvested still needs to be established. If the $\mathrm{Na}^{+}$and $\mathrm{Cl}^{-}$accumulate in the shed leaves but not in the stems, genotypes with salt inclusion could also be considered as good genitors for breeding. If the ions still accumulate in the stems, the genotypes with salt exclusion would be preferred as starting material for breeding; OPM-59 and OPM-71 would be good candidates, with lowest concentrations of $\mathrm{Na}^{+}$and $\mathrm{Cl}^{-}$under salt stress in the shoots. Another quality aspect to consider is the cell wall; stress is known to cause changes in the cell wall composition (Le Gall et al., 2015). Drought stress reduced the cellulose content but increased the hemicellulosic polysaccharides so that available cell wall polysaccharides were more easily released as fermentable sugars during processing (van der Weijde et al., 2016). However, the interaction between cell wall composition and salt stress in Miscanthus is still unexplored.

\section{AUTHOR CONTRIBUTIONS}

CC performed most of the experiments and wrote the paper. $\mathrm{HV}$ assisted with design and execution of the trials and analyses, SD performed the pilot trial, CA, KS, and HM created and provided in vitro material. RV contributed to the supervision, experimental strategy and discussion of the outcomes and to correcting the final manuscript, and CV supervised the study and

\section{REFERENCES}

Adams, P., Thomas, J. C., Vernon, D. M., Bohnert, H. J., and Jensen, R. G. (1992). Distinct cellular and organismic responses to salt stress. Plant Cell Physiol. 33, 1215-1223.

Almeida, D. M., Almadanim, M. C., Lourenço, T., Abreu, I. A., Saibo, N. J. M., and Oliveira, M. M. (2016). "Screening for abiotic stress tolerance in rice: salt, cold, and drought," in Environmental Responses in Plants: Methods and Protocols ed P. Duque (New York, NY: Springer), 155-182.

Ashraf, M., and Harris, P. J. C. (2004). Potential biochemical indicators of salinity tolerance in plants. Plant Sci. 166, 3-16. doi: 10.1016/j.plantsci.2003.10.024

Bassil, E., Coku, A., and Blumwald, E. (2012). Cellular ion homeostasis: emerging roles of intracellular NHX Na/H antiporters in plant growth and development. J. Exp. Bot. 63, 5727-5740. doi: 10.1093/jxb/ers250

Bennett, J., and Khush, G. S. (2003). Enhancing salt tolerance in crops through molecular breeding: a new strategy. J. Crop Prod. 7, 11-65. doi: 10.1300/J144v07n01_02

Bohnert, H. J., Nelson, D. E., and Jensen, R. G. (1995). Adaptations to environmental stresses. Plant Cell 7, 1099-1111. doi: 10.1105/tpc.7.7.1099

Brosse, N., Dufour, A., Meng, X., Sun, Q., and Ragauskas, A. (2012). Miscanthus: a fast-growing crop for biofuels and chemicals production. Biofuels Bioprod. Biorefining 6, 580-598. doi: 10.1002/bbb.1353

Chan-Navarrete, R., Dolstra, O., van Kaauwen, M., Lammerts van Bueren, E. T., and van der Linden, C. G. (2016). Genetic map construction and QTL analysis of nitrogen use efficiency in spinach (Spinacia oleracea L.). Euphytica 208, 621-636. doi: 10.1007/s10681-015-1618-6

Chan-Navarrete, R., Kawai, A., Dolstra, O., Lammerts van Bueren, E. T., and van der Linden, C. G. (2014). Genetic diversity for nitrogen use efficiency in spinach (Spinacia oleracea L.) cultivars using the Ingestad model on hydroponics. Euphytica 199, 155-166. doi: 10.1007/s10681-014-1186-1

Chartzoulakis, K., and Klapaki, G. (2000). Response of two greenhouse pepper hybrids to $\mathrm{NaCl}$ salinity during different growth stages. Sci. Hortic Amsterdam 86, 247-260. doi: 10.1016/S0304-4238(00)00151-5

Chen, Z., Zhou, M., Newman, I. A., Mendham, N. J., Zhang, G., and Shabala, S. (2007). Potassium and sodium relations in salinised barley tissues as a contributed to design, analysis, discussions, and writing of the final manuscript.

\section{FUNDING}

The research has received funding from the European Union consortium OPTIMISC (project ID 289159).

\section{ACKNOWLEDGMENTS}

This work was performed as part of the OPTIMISC project, which received funding from the European Union Seventh Framework Programme (FP7/2007-2013) under grant agreement No. 289159. The authors gratefully acknowledge expert advise from Oene Dolstra on choice of materials, and the expert assistance with the hydroponics system of Geurt Versteeg and Unifarm. We thank IBERS and ILVO for supplying Miscanthus genotypes, and Christel Denneboom for help with in vitro culture.

\section{SUPPLEMENTARY MATERIAL}

The Supplementary Material for this article can be found online at: http://journal.frontiersin.org/article/10.3389/fpls.2017. 00187/full\#supplementary-material basis of differential salt tolerance. Funct. Plant Biol. 34, 150-162. doi: 10.1071/ FP06237

Clifton-Brown, J. C., and Lewandowski, I. (2000). Overwintering problems of newly established Miscanthus plantations can be overcome by identifying genotypes with improved rhizome cold tolerance. New Phytol. 148, 287-294. doi: 10.1046/j.1469-8137.2000.00764.x

Clifton-Brown, J. C., Lewandowski, I., Andersson, B., Basch, G., Christian, D. G., Kjeldsen, J. B., et al. (2001). Performance of 15 Miscanthus genotypes at five sites in Europe. Agron. J. 93, 133-139. doi: 10.2134/agronj2001.93 $51013 \mathrm{x}$

Conde, A., Chaves, M. M., and Geros, H. (2011). Membrane transport, sensing and signaling in plant adaptation to environmental stress. Plant Cell Physiol. 52, 1583-1602. doi: 10.1093/pcp/pcr107

Farouk, S. (2011). Osmotic adjustment in wheat flag leaf in relation to flag leaf area and grain yield per plant. J. Stress Physiol. Biochem. 7, 117-138.

Flowers, T. J., and Yeo, A. R. (1995). Breeding for salinity resistance in crop plants: where next? Aust. J. Plant Physiol. 22, 875-884.

Genc, Y., Oldach, K., Verbyla, A., Lott, G., Hassan, M., Tester, M., et al. (2010). Sodium exclusion QTL associated with improved seedling growth in bread wheat under salinity stress. Theor. Appl. Genet. 121, 877-894. doi: 10.1007/s00122-010-1357-y

Gorham, J., Jones, R. G. W., and Bristol, A. (1990). Partial characterization of the trait for enhanced $\mathrm{K}^{+}-\mathrm{Na}^{+}$discrimination in the D-genome of wheat. Planta 180, 590-597. doi: 10.1007/BF02411458

Greef, J. M., and Deuter, M. (1993). Syntaxonomy of Miscanthus X giganteus Greef-Et-Deu. Angew. Bot. 67, 87-90.

Hassanein, A. M. (1999). Alterations in protein and esterase patterns of peanut in response to salinity stress. Biol. Plantarum 42, 241-248. doi: 10.1023/A:1002112702771

Husain, S., Munns, R., and Condon, A. G. (2003). Effect of sodium exclusion trait on chlorophyll retention and growth of durum wheat in saline soil. Aust. J. Agr. Res. 54, 589-597. doi: 10.1071/AR03032

Jaarsma, R., de Vries, R. S. M., and de Boer, A. H. (2013). Effect of salt stress on growth, $\mathrm{Na}^{+}$accumulation and proline metabolism in potato (Solanum tuberosum) Cultivars. PLoS ONE 8:e60183. doi: 10.1371/journal.pone.0060183 
Jorgensen, U. (1997). Genotypic variation in dry matter accumulation and content of N, $\mathrm{K}$ and $\mathrm{Cl}$ in Miscanthus in Denmark. Biomass Bioenerg. 12, 155-169. doi: 10.1016/S0961-9534(97)00002-0

Kerepesi, I., and Galiba, G. (2000). Osmotic and salt stress-induced alteration in soluble carbohydrate content in wheat seedlings. Crop Sci. 40, 482-487. doi: $10.2135 /$ cropsci2000.402482x

Khan, M. A., Ungar, I. A., and Showalter, A. M. (2000). Effects of sodium chloride treatments on growth and ion accumulation of the halophyte Haloxylon recurvum. Commun. Soil Sci. Plant 31, 2763-2774. doi: 10.1080/00103620009370625

Khatkar, D., and Kuhad, M. S. (2000). Short-term salinity induced changes in two wheat cultivars at different growth stages. Biol. Plantarum 43, 629-632. doi: 10.1023/A:1002868519779

Krishnamurthy, L., Serraj, R., Hash, C. T., Dakheel, A. J., and Reddy, B.V.S. (2007). Screening sorghum genotypes for salinity tolerant biomass production. Euphytica 156, 15-24. doi: 10.1007/s10681-006-9343-9

Le Gall, H., Philippe, F., Domon, J.-M., Gillet, F., Pelloux, J., and Rayon, C. (2015). Cell wall metabolism in response to abiotic stress. Plants 4, 112-166. doi: $10.3390 /$ plants 4010112

Lewandowski, I., Clifton-Brown, J., Trindade, L. M., van der Linden, C. G., Schwarz, K.-U., Müller-Sämann, K., et al. (2016). Progress on optimizing miscanthus biomass production for the european bioeconomy: results of the eu fp7 project optimisc. Front. Plant Sci. 7:1620. doi: 10.3389/fpls.2016.01620

Li, X. Y., Wang, J. F., Lin, J. X., Wang, Y., and Mu, C. S. (2014). Rhizomes help the forage grass leymus chinensis to adapt to the salt and alkali stresses. Sci. World J. 2014:213401. doi: 10.1155/2014/213401

Lin, H. X., Zhu, M. Z., Yano, M., Gao, J. P., Liang, Z. W., Su, W. A., et al. (2004). QTLs for $\mathrm{Na}^{+}$and $\mathrm{K}^{+}$uptake of the shoots and roots controlling rice salt tolerance. Theor. Appl. Genet. 108, 253-260. doi: 10.1007/s00122-003-1421-y

Lindsay, M. P., Lagudah, E. S., Hare, R. A., and Munns, R. (2004). A locus for sodium exclusion (Nax1), a trait for salt tolerance, mapped in durum wheat. Funct. Plant Biol. 31, 138-1114. doi: 10.1071/FP04111

Long, N. V., Dolstra, O., Malosetti, M., Kilian, B., Graner, A., Visser, R. G. F., et al. (2013). Association mapping of salt tolerance in barley (Hordeum vulgare L.). Theor. Appl. Genet. 126, 2335-2351. doi: 10.1007/s00122-013-2139-0

Luo, Q., Yu, B., and Liu, Y. (2005). Differential sensitivity to chloride and sodium ions in seedlings of Glycine max and G. soja under $\mathrm{NaCl}$ stress. J. Plant Physiol. 162, 1003-1132. doi: 10.1016/j.jplph.2004.11.008

Mann, J. J., Barney, J. N., Kyser, G. B., and DiTomaso, J. M. (2013). Root system dynamics of miscanthus $\mathrm{x}$ giganteus and Panicum virgatum in response to rainfed and irrigated conditions in california. Bioenerg. Res. 6, 678-687. doi: 10.1007/s12155-012-9287-y

Maser, P., Eckelman, B., Vaidyanathan, R., Horie, T., Fairbairn, D. J., Kubo, M., et al. (2002). Altered shoot/root $\mathrm{Na}^{+}$distribution and bifurcating salt sensitivity in Arabidopsis by genetic disruption of the $\mathrm{Na}^{+}$transporter AtHKTI1. Febs Lett. 531, 157-161. doi: 10.1016/S0014-5793(02)03488-9

Munns, R., and James, R. A. (2003). Screening methods for salinity tolerance: a case study with tetraploid wheat. Plant Soil 253, 201-218. doi: 10.1023/A:1024553303144

Munns, R., James, R. A., Xu, B., Athman, A., Conn, S. J., Jordans, C., et al. (2012). Wheat grain yield on saline soils is improved by an ancestral $\mathrm{Na}^{+}$transporter gene. Nat. Biotechnol. 30, 360-364. doi: 10.1038/nbt.2120

Munns, R., and Tester, M. (2008). Mechanisms of salinity tolerance. Annu. Rev. Plant Biol. 59, 651-681. doi: 10.1146/annurev.arplant.59.032607.092911

Nguyen, V. L., Ribot, S. A., Dolstra, O., Niks, R. E., Visser, R. G. F., and van der Linden, C. G. (2013). Identification of quantitative trait loci for ion homeostasis and salt tolerance in barley (Hordeum vulgare L.). Mol. Breed. 31, 137-152. doi: 10.1007/s11032-012-9777-9

Parida, A. K., and Das, A. B. (2005). Salt tolerance and salinity effects on plants: a review. Ecotox Environ. Safe. 60, 324-349. doi: 10.1016/j.ecoenv.2004.06.010

Platten, J. D., Egdane, J. A., and Ismail, A. M. (2013). Salinity tolerance, $\mathrm{Na}^{+}$exclusion and allele mining of HKT1;5 in Oryza sativa and $O$. glaberrima: many sources, many genes, one mechanism? BMC Plant Biol. 13:32. doi: 10.1186/1471-2229-13-32

Plazek, A., Dubert, F., Koscielniak, J., Tatrzanska, M., Maciejewski, M., Gondek, K., et al. (2014). Tolerance of Miscanthus x giganteus to salinity depends on initial weight of rhizomes as well as high accumulation of potassium and proline in leaves. Ind. Crop Prod. 52, 278-285. doi: 10.1016/j.indcrop.2013.10.041

Qadir, M., Quillérou, E., Nangia, V., Murtaza, G., Singh, M., Thomas, R. J., et al. (2014). Economics of salt-induced land degradation and restoration. Natl. Resour. Forum 38, 282-295. doi: 10.1111/1477-8947.12054

Rajendran, K., Teater, M., and Roy, S. J. (2009). Quantifying the three main components of salinity tolerance in cereals. Plant Cell Environ. 32, 237-249. doi: 10.1111/j.1365-3040.2008.01916.x

Rengasamy, P. (2010a). Osmotic and ionic effects of various electrolytes on the growth of wheat. Soil Res. 48, 120-124. doi: 10.1071/SR09083

Rengasamy, P. (2010b). Soil processes affecting crop production in salt-affected soils. Funct. Plant Biol. 37, 613-620. doi: 10.1071/FP09249

Schmer, M. R., Vogel, K. P., Mitchell, R. B., and Perrin, R. K. (2008). Net energy of cellulosic ethanol from switchgrass. Proc. Natl. Acad. Sci. U.S.A. 38, 464-469. doi: 10.1073/pnas.0704767105

Shabala, S., and Cuin, T. A. (2008). Potassium transport and plant salt tolerance. Physiol. Plantarum 133, 651-669. doi: 10.1111/j.1399-3054.2007.01008.x

Somerville, C., Youngs, H., Taylor, C., Davis, S. C., and Long, S. P. (2010). Feedstocks for lignocellulosic biofuels. Science 329, 790-792. doi: $10.1126 /$ science. 1189268

Stavridou, E., Hastings, A., Webster, R. J., and Robson, P. R. H. (2016). The impact of soil salinity on the yield, composition and physiology of the bioenergy grass Miscanthus $\times$ giganteus. GCB Bioenergy 9, 92-104. doi: 10.1111/gcbb.12351

Sun, Q., Yamada, T., and Takano, T. (2014). Salinity effects on germination, growth, photosynthesis, and ion accumulation in wild Miscanthus sinensis anderss. Popul. Crop Sci. 54, 2760-2771. doi: 10.2135/cropsci2013.09.0636

Tavakkoli, E., Fatehi, F., Rengasamy, P., and McDonald, G. K. (2012). A comparison of hydroponic and soil-based screening methods to identify salt tolerance in the field in barley. J. Exp. Bot. 63, 3853-3867. doi: $10.1093 /$ jxb/ers085

Teakle, N. L., and Tyerman, S. D. (2010). Mechanisms of $\mathrm{Cl}^{-}$transport contributing to salt tolerance. Plant Cell Environ. 33, 566-589. doi: 10.1111/j.1365-3040.2009.02060.x

Thomson, M. J., de Ocampo, M., Egdane, J., Rahman, M. A., Sajise, A. G., Adorada, D. L., et al. (2010). Characterizing the Saltol quantitative trait locus for salinity tolerance in rice. Rice 3, 148-160. doi: 10.1007/s12284-010-9053-8

van der Weijde, T., Huxley, L. M., Hawkins, S., Sembiring, E. H., Farrar, K., Dolstra, O., et al. (2016). Impact of drought stress on growth and quality of Miscanthus for biofuel production. GCB Bioenergy. doi: 10.1111/gcbb.12382. [Epub ahead of print].

Wang, Y., and Nii, N. (2000). Changes in chlorophyll, ribulose bisphosphate carboxylase-oxygenase, glycine betaine content, photosynthesis and transpiration in Amaranthus tricolor leaves during salt stress. J. Hortic. Sci. Biotechnol. 75, 623-627. doi: 10.1080/14620316.2000.11511297

Xue, D., Huang, Y., Zhang, X., Wei, K., Westcott, S., Li, C., et al. (2009). Identification of QTLs associated with salinity tolerance at late growth stage in barley. Euphytica 169, 187-196. doi: 10.1007/s10681-009-9919-2

Zhifang, G., and Loescher, W. H. (2003). Expression of a celery mannose 6phosphate reductase in Arabidopsis thaliana enhances salt tolerance and induces biosynthesis of both mannitol and a glucosyl-mannitol dimer. Plant Cell Environ. 26, 275-283. doi: 10.1046/j.1365-3040.2003.00958.x

Zub, H. W., and Brancourt-Hulmel, M. (2010). Agronomic and physiological performances of different species of Miscanthus, a major energy crop. A Review. Agron. Sustain. Dev. 30, 201-214. doi: 10.1051/agro/2009034

Conflict of Interest Statement: The authors declare that the research was conducted in the absence of any commercial or financial relationships that could be construed as a potential conflict of interest.

Copyright $\odot 2017$ Chen, van der Schoot, Dehghan, Alvim Kamei, Schwarz, Meyer, Visser and van der Linden. This is an open-access article distributed under the terms of the Creative Commons Attribution License (CC BY). The use, distribution or reproduction in other forums is permitted, provided the original author(s) or licensor are credited and that the original publication in this journal is cited, in accordance with accepted academic practice. No use, distribution or reproduction is permitted which does not comply with these terms. 